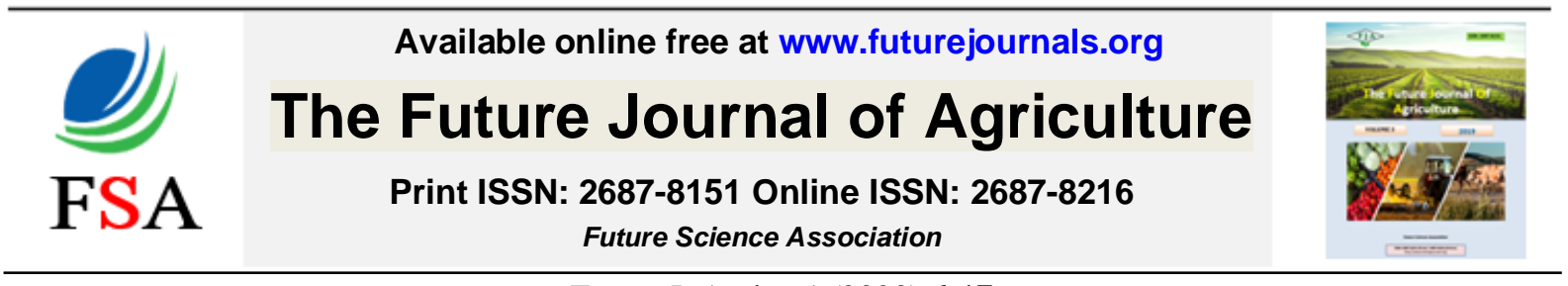

Future J. Agric., 1 (2020) 6-17

OPEN ACCES

DOI: 10.37229/fsa.fja.2020.01.20

\title{
IMPROVING FLOWERING AND FRUITING OF VALENCIA ORANGE TREES BY USING HUMIC ACID AND SOME BIOFERTILIZERS
}

\author{
Hany A. El-Alakmy ${ }^{1 *}$ and Mohamed M. Ibrahim ${ }^{2}$ \\ ${ }^{1}$ Plant Production Dept., Fac. Agric. and Environ. Sci., Arish Univ., Egypt \\ ${ }^{2}$ Hort. Dept., Fac. Agric., Zagazig Univ., Egypt
}

"Corresponding author: Hando_100@ hotmail.com Received: 20 Dec. 2019 ; Accepted: 20 Jan. 2020

\begin{abstract}
This study was conducted to evaluate the effect of humic acid and biofertilization by Nitrobein and rhizobacterin on flowering, yield and fruit quality of Valencia orange (Citrus sinenses) trees budded on sour orange rootstock and grown in a loamy sand soil under drip irrigation system at El-Kassasin Horticultural Research Station Farm, Ismailia Governorate, Egypt during two successive seasons 2017 and 2018. Four different doses of humic acid $(0,50,100$ and $150 \mathrm{~g} /$ tree) and two types of biofertilizers i.e., nitrobein and rhizobacterin were added as soil application through drip irrigation (on distance 100-150 $\mathrm{cm}$ from tree trunk and $30 \mathrm{~cm}$ depth around each tree) at three equal doses in February, April and June at the rate of $2 \mathrm{~L} / \mathrm{fed}$. for factorial experiment under two factors. The results indicated that all application of different levels of humic acid alone or in combination with biofertilizers had a positive effect on increased flowering characteristics, fruit set percentage and total yield as well as improved fruit physical and chemical characters. In addition, interaction treatment between rhizobacterin and humic acid at $150 \mathrm{~g} /$ tree was the most effective treatment in enhancing flowering parameters (leafy inflorescences and flowering percentage on leafy and woody inflorescences) as well as total yield, average fruit weight, total soluble solids (TSS), TSS/ acid ratio, vitamin C content and total sugars and decreased the woody inflorescences \%, percentages of both the total acidity and reducing sugars in fruit juice. In addition, fruit set percentage, fruit juice weight and volume were the best on trees biofrtilized with nitrobein and humic acid at $150 \mathrm{~g} /$ tree in both seasons.
\end{abstract}

Key words: Valencia orange, humic acid, nitrobein, rhizobacterin, flowering, fruit quality.

\section{INTRODUCTION}

Citrus is considered as one of the premier fruit crops all over the world, both in terms of planting area and production. Egypt ranking as the sixth largest producer of orange all over the world, and also, considered the largest exporter of orange in the world (Abobatta, 2018). The cultivated area reached to (204095 ha) representing about $29 \%$ of the total fruit area (700854 ha), the total fruitful area of citrus reached about (175734 ha) approximately, which produce about 4272886 metric tons, from which around 1.34 million tons are exported according to Ministry of Agriculture (2018), Egypt ranking as the sixth biggest producer of orange throughout the world after Brazil, China, US, EU, and Mexico according to Ministry of Agriculture and Land Reclamation (Annual report Statistical, 2018).
In most cases, the exportation of citrus was mainly affected by different factors such as accumulative harmful of nitrate or nitrite, phosphates, sulphat and other chemical in fruit tissue which as a result of excessive use of chemical fertilization (Montasser, et al., 2003 \& ElKhawaga and Maklad, 2013). Thus, using biofertilizers that contain different microbial strains hassled to a decrease in the use of chemical fertilizers and has provided high quality products free of harmful agrochemicals for human safety (Mahfouz and Sharaf-Eldin, 2007 \& AbdAlhamid et al., 2015), these were the best way for reaching to a good product (increase crop yield by 10-40 \%) with high quality (Jugnake et al., 2017), increasing emphasis on maintain of soil health (fixing nitrogen up to $40-50 \%$ ) and improve soil texture, $\mathrm{pH}$ and other properties of soil (Youssef and Eissa, 2014), minimize environmental pollution and cut down on the use of chemical fertilization 
(El-Khawaga, 2007). So, it was safe for human, animal and environmental (El-Khawaga and Maklad, 2013). Studies have indicated that, nitrobein and rhizobacterin as biofertilizer could improve growth and yield (El-Badawy, 2017) on Valencia orange. Aseri et al. (2008) found that the use of biofertilizers gave a significant improvement of fruits of pomegranate in India as well as enhancing the rhizosphere microbial activity and concentration of various nutrients.

Humic acid is one of the bio-stimulants which promote plant growth (higher biomass production) by accelerating cell division (Sindha et $\boldsymbol{a l}$., 2018) and stimulate plant enzymes and increase production by acting on mechanisms involved in: cell respiration, photosynthesis, protein synthesis, water and nutrient uptake, enzyme activities (Chen $\boldsymbol{e t} \boldsymbol{a l}$., 2004; Aseri et al., 2008 and Abd El-Rhman, 2017). Farag (2006) noted that humic acid significantly decreased nitrogen as nitrate and nitrite content and improved yield and fruit quality of treated vines. Sindha et al. (2018) found that the application of humic acid at $1 \%$ was most effective treatment and recorded significantly maximum fruit yield/plant, fruit weight, fruit diameter, total soluble solids, total sugar, reducing sugar, non-reducing sugar, ascorbic acid shelf life of custard apple (Annona squamosa L.) cv. local. Abd El-Rhman (2017) noticed that the addition of potassium humate at $25,50 \mathrm{~g} /$ tree resulted in a significant increase growth yield and fruit quality of Manfalouty pomegranate trees compared with other treatments. Eissa (2003) and Fathy et al. (2010) found that humic acid treatments (foliar and soil applications) markedly increased yield and fruit physical and chemical properties (fruit firmness, juice SSC and $\mathrm{SSC}$ / acidity ratio) of 'Canino' apricot.
Therefore, the present study was undertaken to study the effects of application of humic acid and some biofertilizer (nitrobein and rhizobacterin) on flowering, yield and fruit quality of Valencia orange trees.

\section{MATERIAL AND MOTHODS}

This study was conducted during the seasons of 2017 and 2018 on Valencia orange (Citrus sinenses) trees of about 22 years old budded on sour orange (C. aurantium L.) rootstock, spaced at $5 \times 5 \mathrm{~m}^{2}$ apart with about 168 trees/ feddan. The trees cultivated in El- Kassasin Horticultural Research Station Farm, Ismailia Governorate, Egypt and grown in a loamy sand soil under drip irrigation system. Samples of soil were taken from different sites of the experimental regions to determine physical and chemical properties of the soil according to (Page $\boldsymbol{e t}$ al., 1982) as shown in Table (1). The trees were chosen for the present study almost uniform in vigor and apparently healthy and subjected to the normal cultural practices. The experimental trees have nearly the same height, volume and diameter received uniform horticultural practices except for soil biofertilization application treatments. All trees received $1.0 \mathrm{~kg}$ mono-calcium phosphate per tree mixed with $10 \mathrm{~kg} /$ tree organic manure added in rounded trenches $(30 \mathrm{~cm}$ depth and $100-150 \mathrm{~cm}$ from tree trunk) around the tree canopy, $\mathrm{N}$ was added $100 \mathrm{~kg}$ per feddan/ year (equal doses from February to October) and $90 \mathrm{~kg} \mathrm{~K}_{2} \mathrm{O}$ (three doses: March, June and October) were added as fertigation. Micronutrients (Fe 500 ppm, Mn 250 ppm and Zn $250 \mathrm{ppm}$ ) were applied as foliar sprays 4 times/ year i.e. in April, June, August and October.

Table 1. Main physical properties and chemical constituents of the orchard soil under the experimental trees

\begin{tabular}{|c|c|c|c|c|c|c|c|c|c|c|}
\hline \multicolumn{11}{|c|}{ Main physical properties } \\
\hline \multirow{2}{*}{$\begin{array}{c}\text { Sample depth } \\
(\mathrm{cm})\end{array}$} & \multicolumn{6}{|c|}{ Particle size distribution (\%) } & \multirow{2}{*}{\multicolumn{2}{|c|}{ Soil textural }} & \multirow{2}{*}{\multicolumn{2}{|c|}{$\underset{(\%)}{\text { O. M. }}$}} \\
\hline & \multicolumn{2}{|c|}{ Sand } & \multicolumn{2}{|c|}{ Silt } & \multicolumn{2}{|c|}{ Clay } & & & & \\
\hline $0-30$ & \multicolumn{2}{|c|}{69.71} & \multicolumn{2}{|c|}{18.20} & \multicolumn{2}{|c|}{12.40} & \multicolumn{2}{|c|}{ Loamy sand } & \multicolumn{2}{|r|}{0.08} \\
\hline $30-60$ & \multicolumn{2}{|c|}{68.14} & \multicolumn{2}{|c|}{19.15} & \multicolumn{2}{|c|}{12.71} & \multicolumn{2}{|c|}{ Loamy sand } & \multicolumn{2}{|r|}{0.07} \\
\hline $60-90$ & \multicolumn{2}{|c|}{67.98} & \multicolumn{2}{|c|}{20.11} & \multicolumn{2}{|c|}{11.91} & \multicolumn{2}{|c|}{ Loamy sand } & \multicolumn{2}{|r|}{0.06} \\
\hline \multicolumn{11}{|c|}{ Main chemical constituents } \\
\hline \multirow{2}{*}{$\begin{array}{l}\text { Sample depth } \\
(\mathrm{cm})\end{array}$} & \multirow{2}{*}{ pH } & \multirow{2}{*}{$\begin{array}{c}\mathrm{EC} \\
\left(\mathrm{ds} \mathrm{cm}^{-1}\right)\end{array}$} & \multicolumn{4}{|c|}{ Cations $\left(\right.$ meq $\left.\mathrm{I}^{-1}\right)$} & \multicolumn{4}{|c|}{ Anions (meq $\mathrm{I}^{-1}$ ) } \\
\hline & & & $\mathbf{C a}^{++}$ & $\mathbf{M g}^{++}$ & $\mathrm{Na}^{+}$ & $\mathbf{K}^{+}$ & $\mathrm{CO}_{3}{ }^{--}$ & $\mathrm{HCO}_{3}^{-}$ & So $4^{--}$ & $\mathrm{Cl}^{-}$ \\
\hline $0-30$ & 8.20 & 0.87 & 3.90 & 2.70 & 1.85 & 0.55 & - & 1.30 & 3.15 & 4.55 \\
\hline $30-60$ & 8.23 & 0.85 & 4.08 & 2.44 & 2.37 & 0.63 & - & 1.45 & 3.21 & 4.86 \\
\hline $60-90$ & 8.50 & 0.82 & 4.16 & 2.21 & 2.92 & 0.67 & - & 1.63 & 3.22 & 5.11 \\
\hline
\end{tabular}




\section{The Tested Treatments}

\section{Humic acid treatments}

The different doses of humic acid as commercially available potassium humate were evaluated on Valencia orange trees and added to the soil in a small hole under the periphery of the trees three times i.e., February, April and June. Humic acid treatments were set as given bellow:
1. Control (untreated)
2. $50 \mathrm{~g}$ humic acid/ tree
3. $100 \mathrm{~g}$ humic acid/ tree
4. $150 \mathrm{~g}$ humic acid/ tree

\section{Biofertilization treatments}

Two types of biofertilizers i.e., nitrobein (a commercial product of biofertilizer contain a specific strains of Azotobacter chroococcum and Azospirillum baracillense, conc. 10 cells/ ml) and rhizobacterin (a commercial product that contains a specific strain of Rhizobiusm sp. which fixes atmospheric $\mathrm{N}_{2}$, conc. 10 cells/ ml) were added as soil application through drip irrigation three equal doses in February, April and June at the rate of $2 \mathrm{~L} /$ fed. according to General Organization for Agriculture Equalization Fund (GOAEF, 1999). Biofertilizers were inoculated in $100-150 \mathrm{~cm}$ from tree trunk and $30 \mathrm{~cm}$ depth around each tree.

\section{Measurements}

\section{Flowering characteristics and fruit set percentage}

During spring growth cycle, leafy and woody inflorescences percentage (\%) were estimated by counting the number of each type at the early April, and calculated in relative to the total number of inflorescences. Also, number of flowers for both inflorescences were recorded then percentage of flowering in both inflorescences were calculated. Initial fruit set percentage $(\%)$ were estimated by counting the number of flowers on the labeled shoots at the balloon stage by the mid-March of each season. After fruit set, the setted fruitlets were counted at the same branches at the April in the two seasons. Fruit set percentage was calculated by divided the number of fruitlettes by total number of flowers and multiplying the product $\times 100$.

\section{Yield component and fruit characteristics}

At harvesting date if Valencia orange fruits in April-May, number of harvested fruits/ tree were recorded, the total fruit weight per tree (total yield/ tree in $\mathrm{kg}$ ) was determined when the fruits yellow color reached about $50 \%$ and TSS/ acid ratio reached about $10-11 \%$ according to (Hikal, 2000). Samples of 20 fruits per replicate were randomly taken to determine some physical and chemical properties involved: average fruit weight $(\mathrm{g})$ and juice volume/ fruit $(\mathrm{ml})$. Total acidity percentage in fruit juice (as citric acid) was determined by titration against $0.1 \quad \mathrm{~N}$ sodium hydroxide using phenolphthalein as an indicator (A.O.A.C.,1995). Total soluble solids (TSS \%) was determined in fruit juice using a hand refractometer, the TSS/ acid ratio was also calculated. Vitamin C content (mg / $100 \mathrm{ml}$ juice) was determined in fruit juice by titration against 2,6-dichlorophenol indophenol dye following the method illustrated in the A.O.A.C. (1995). In addition, total and reducing sugars percentages were determined in fruit juice according to Lane \& Eynon (1960).

\section{Experimental design and statistical analysis}

The layout of the experiment was factorial in randomized complete block design (RCBD) with twelve treatments with two factors, the first factor was the humic acid treatments, whereas the second one was the different biofertilization treatments and each treatment was applied on six trees shared between three replicates ( 4 humic acid treatments $x$ 3 biofertilization application $\times 6$ replicates). The obtained data were statistically analyzed using the MSTATC computer program (Russell, 1986). Duncan's multiple range test was used to separate treatment means to found significantly different in the analysis of variance (Duncan, 1955).

\section{RESULT AND DISCUSSION}

\section{Flowering characteristics}

\section{1- Leafy inflorescences $(\%)$}

Data presented in Table (2) showed that leafy inflorescences percentage was significantly increased under different biofertilization compared to control treatment in both seasons. Rhizobacterin biofertilization treatments gave highest leafy inflorescences percentage (78.39 and $81.23 \%$ ) when compared to control treatment in the first and second season, respectively. The differences between nitrobein and rhizobacterin on leafy inflorescences were insignificant in the first season only. The lowest values recorded by control treatment (69.36 and $69.50 \%$ ) in the two seasons, respectively. As for, the effect of humic acid treatments on leafy inflorescences percentage, it is clear that humic acid at $150 \mathrm{~g} /$ tree gave the highest significantly in leafy inflorescences values (78.43 and $79.56 \%$ ), followed by humic acid at $100 \mathrm{~g} /$ tree treatment $(76.50$ and $77.78 \%$ ), while control treatment was the lowest values (71.55 and $72.48 \%$ ) during both seasons, respectively. The interaction with rhizobacterin or nitrobein + humic acid at $150 \mathrm{~g} /$ tree gave the highest leafy inflorescences percentage (81.33 and $83.01 \%$ ) and (80.19 and $81.79 \%)$ compared to other interactions during both seasons. While, untreated treatment gave the lowest values (65.78 and 64.55 $\%)$ in the two seasons, respectively. Significant 
differences were found in leafy inflorescences percentage between all interactions as compared with the control in both seasons. These data are in line with those obtained by Khattab et al. (2012) on pomegranate; Hidayatullah et al. (2018) on apple trees and Abd-Alhamidet al. (2015) on olive trees.

\section{2- Woody inflorescences (\%)}

The illustrated data in the Table (2) indicted that woody inflorescences was decreased significantly with different biofertilizer treatments in both seasons. Control treatment (untreated of biofertilizer) gave the highest values of woody inflorescences (30.64 and $30.50 \%$ ) in the two seasons, respectively. In contrary, rhizobacterin biofertilizer gave the lowest values in this respect (21.61 and $18.77 \%$ ) during the first and second seasons respectively. Nitrobein biofertilizer treatment was in between. The treatment of humic acid at $150 \mathrm{~g} /$ tree significantly decreased woody inflorescences (21.57 and $20.44 \%$ ) in both seasons, respectively. While, control treatment (untreated of humic acid) gave the highest values of woody inflorescences (28.45 and $27.52 \%$ ) in the first and second seasons, respectively. As for, the interaction effect between biofertilization and humic acid treatments on woody inflorescences percentage was significant reduction in woody inflorescences percentage, the interaction between rhizobacterin with humic acid at $150 \mathrm{~g} /$ tree gave the least values (18.67 and $16.99 \%$ ) compared to other interactions in both seasons, respectively. On the contrary, the untreated interaction treatment produced the highest woody inflorescences percentage and gave the highest values (34.22 and $35.45 \%)$ in the two seasons, respectively. These data are in line with those obtained by Abobatta (2014) who concluded that humic treatments were significantly reduced the woody inflorescences percentage on Valencia orange trees.

Table 2. Effect of humic acid and biofertilization treatments on leafy and woody inflorescences percentage of Valencia orange trees during 2017 and 2018 seasons

\begin{tabular}{|c|c|c|c|c|c|c|c|c|}
\hline \multirow{2}{*}{$\begin{array}{l}\text { Humic acid } \\
\text { treatments }\end{array}$} & \multicolumn{4}{|c|}{ Leafy inflorescences $(\%)$} & \multicolumn{4}{|c|}{ Woody inflorescences (\%) } \\
\hline & Control & Nitrobein & Rhizobacterin & $\begin{array}{c}\text { Average } \\
\text { H.A. }\end{array}$ & Control & Nitrobein & Rhizobacterin & $\begin{array}{c}\text { Average } \\
\text { H.A. }\end{array}$ \\
\hline \multicolumn{9}{|c|}{ Season 2017} \\
\hline Control & $65.78 \mathrm{f}$ & $73.11 \mathrm{c}$ & $75.76 \mathrm{bc}$ & $71.55 \mathrm{D}$ & $34.22 \mathrm{a}$ & $26.89 \mathrm{c}$ & $24.24 \mathrm{~d}$ & $28.45 \mathrm{~A}$ \\
\hline $50 \mathrm{~g} /$ tree & $67.28 \mathrm{e}$ & $76.45 b$ & $76.88 \mathrm{~b}$ & 73.54 C & $32.72 \mathrm{ab}$ & $23.55 \mathrm{e}$ & $23.12 \mathrm{e}$ & 26.46 B \\
\hline $100 \mathrm{~g} /$ tree & $70.59 \mathrm{~d}$ & $79.32 \mathrm{ab}$ & $79.58 \mathrm{ab}$ & 76.50 B & $29.41 \mathrm{~b}$ & $20.68 \mathrm{f}$ & $20.42 \mathrm{f}$ & 23.50 C \\
\hline $150 \mathrm{~g} /$ tree & $73.77 \mathrm{c}$ & $80.19 \mathrm{a}$ & $81.33 \mathrm{a}$ & $78.43 \mathrm{~A}$ & $26.23 c$ & $19.81 \mathrm{~g}$ & $18.67 \mathrm{~h}$ & 21.57 D \\
\hline Average B.F. & $69.36 \mathrm{~B}$ & $77.27 \mathrm{~A}$ & $78.39 \mathrm{~A}$ & & $30.64 \mathrm{~A}$ & 22.73 B & 21.61 B & \\
\hline \multicolumn{9}{|c|}{ Season 2018} \\
\hline Control & $64.55 \mathrm{~g}$ & $75.30 \mathrm{~cd}$ & $77.58 \mathrm{c}$ & $72.48 \mathrm{C}$ & $35.45 \mathrm{a}$ & $24.70 \mathrm{e}$ & $22.42 \mathrm{f}$ & $27.52 \mathrm{~A}$ \\
\hline $50 \mathrm{~g} /$ tree & $68.82 \mathrm{f}$ & $77.98 \mathrm{c}$ & $81.49 \mathrm{~b}$ & 76.10 B & $31.18 \mathrm{~b}$ & $22.02 \mathrm{f}$ & $18.51 \mathrm{~h}$ & 23.90 B \\
\hline $100 \mathrm{~g} /$ tree & $70.74 \mathrm{e}$ & $79.74 \mathrm{bc}$ & $82.85 \mathrm{ab}$ & 77.78 B & $29.26 \mathrm{c}$ & $20.26 \mathrm{~g}$ & $17.15 \mathrm{i}$ & 22.22 BC \\
\hline $150 \mathrm{~g} /$ tree & $73.88 \mathrm{~d}$ & $81.79 \mathrm{~b}$ & $83.01 \mathrm{a}$ & $79.56 \mathrm{~A}$ & $26.12 \mathrm{~d}$ & $18.21 \mathrm{~h}$ & $16.99 \mathrm{j}$ & $20.44 \mathrm{C}$ \\
\hline Average B.F. & $69.50 \mathrm{C}$ & $78.70 \mathrm{~B}$ & 81.23 A & & $30.50 \mathrm{~A}$ & $21.30 \mathrm{~B}$ & $18.77 \mathrm{C}$ & \\
\hline
\end{tabular}

Means having the same letter(s) within the same column are not significantly different according to Duncans multiple range tests at $5 \%$ level of probability.

\section{3- Flowering percentage on leafy and woody inflorescences $(\%)$}

As shown in Table (3) percentage of flowers in leafy and woody inflorescences were significantly affected by conducted biofertilizer treatments in both seasons. Rhizobacterin biofertilizer resulted in the highest flowers percentage in leafy and woody inflorescences (3.45 and $3.93 \%)$ and (2.57 and 2.64 $\%)$ in the two seasons, respectively. On the other hand, the least values were obtained by control treatment (untreated of biofertilizer) (2.24 and 2.52 $\%)$ and (1.54 and $1.34 \%)$ in both seasons, respectively. Humic acid at $150 \mathrm{~g} /$ tree treatment improved flowers number in leafy inflorescences and woody recorded the highest values (3.19 and $3.64 \%$ ) and (2.62 and $2.63 \%$ ), followed by humic acid at $100 \mathrm{~g} /$ tree treatment (3.03 and $3.45 \%)$ and (2.44 and $2.45 \%$ ) during both seasons, respectively. While, control treatment (untreated of humic acid) gave the lowest values of leafy and woody inflorescences (2.38 and $2.66 \%$ ) and (1.85 and 1.90 $\%)$ in the first and second season, respectively. The interaction with rhizobacterin + humic acid at $150 \mathrm{~g} /$ tree produced the highest flowers in leafy and woody inflorescences (3.89 and $4.43 \%$ ) and (2.95 and 3.04 $\%)$ in both seasons, respectively. Untreated interaction with humic acid or biofertilizer gave the least values (1.91 and $2.02 \%)$ and (1.54 and $1.34 \%$ ) in this concern during both seasons. Moreover, the 
statistical analysis revealed that all interactions significantly increased flowers number in leafy and woody inflorescences as compared with the control treatment during both seasons. These results are in line with those obtained by Khattab et al. (2012) who concluded that adding humic acid can be enhancing flowers number of pomegranate tree.

Table 3. Effect of humic acid and biofertilization treatments on flowering percentage on leafy and woody inflorescences of Valencia orange trees during 2017 and 2018 seasons

\begin{tabular}{|c|c|c|c|c|c|c|c|c|}
\hline \multirow{2}{*}{$\begin{array}{l}\text { Humic acid } \\
\text { treatments }\end{array}$} & \multicolumn{4}{|c|}{ Flowering $\%$ on leafy inflorescences $(\%)$} & \multicolumn{4}{|c|}{ Flowering $\%$ on woody inflorescences $(\%)$} \\
\hline & Control & Nitrobein & Rhizobacterin & $\begin{array}{c}\text { Average } \\
\text { H.A. }\end{array}$ & Control & Nitrobein & Rhizobacterin & $\begin{array}{c}\text { Average } \\
\text { H.A. }\end{array}$ \\
\hline \multicolumn{9}{|c|}{ Season 2017} \\
\hline Control & $1.91 \mathrm{f}$ & $2.45 \mathrm{~cd}$ & $2.77 \mathrm{bcd}$ & $2.38 \mathrm{~B}$ & $1.54 \mathrm{e}$ & $1.97 \mathrm{~cd}$ & $2.04 \mathrm{c}$ & $1.85 \mathrm{~B}$ \\
\hline $50 \mathrm{~g} /$ tree & $2.19 \mathrm{e}$ & $2.81 \mathrm{bc}$ & $3.45 \mathrm{ab}$ & $2.82 \mathrm{AB}$ & $1.77 \mathrm{~d}$ & $2.33 \mathrm{bc}$ & $2.61 \mathrm{~b}$ & $2.24 \mathrm{~B}$ \\
\hline $100 \mathrm{~g} /$ tree & $2.37 \mathrm{~d}$ & $3.04 \mathrm{~b}$ & $3.68 \mathrm{a}$ & $3.03 \mathrm{~A}$ & $1.92 \mathrm{~cd}$ & $2.66 \mathrm{~b}$ & $2.73 \mathrm{ab}$ & $2.44 \mathrm{AB}$ \\
\hline $150 \mathrm{~g} /$ tree & $2.49 \mathrm{~cd}$ & $3.19 \mathrm{~b}$ & $3.89 \mathrm{a}$ & $3.19 \mathrm{~A}$ & $2.03 \mathrm{c}$ & $2.95 \mathrm{a}$ & $2.88 \mathrm{a}$ & $2.62 \mathrm{~A}$ \\
\hline Average B.F. & $2.24 \mathrm{~B}$ & $2.87 \mathrm{AB}$ & $3.45 \mathrm{~A}$ & & $1.81 \mathrm{~B}$ & $2.48 \mathrm{~A}$ & $2.57 \mathrm{~A}$ & \\
\hline \multicolumn{9}{|c|}{ Season 2018} \\
\hline Control & $2.02 \mathrm{f}$ & $2.79 \mathrm{de}$ & $3.16 \mathrm{~cd}$ & $2.66 \mathrm{~B}$ & $1.34 \mathrm{f}$ & $2.25 \mathrm{c}$ & $2.10 \mathrm{~cd}$ & $1.90 \mathrm{~B}$ \\
\hline $50 \mathrm{~g} /$ tree & $2.52 \mathrm{ef}$ & $3.20 \mathrm{bcd}$ & $3.93 \mathrm{ab}$ & $3.22 \mathrm{AB}$ & $1.72 \mathrm{e}$ & $2.66 \mathrm{bc}$ & $2.69 \mathrm{~b}$ & $2.36 \mathrm{AB}$ \\
\hline $100 \mathrm{~g} /$ tree & $2.68 \mathrm{def}$ & $3.47 \mathrm{bc}$ & $4.20 \mathrm{a}$ & $3.45 \mathrm{~A}$ & $1.80 \mathrm{de}$ & $2.74 \mathrm{~b}$ & $2.81 \mathrm{ab}$ & $2.45 \mathrm{AB}$ \\
\hline $150 \mathrm{~g} /$ tree & $2.84 \mathrm{~d}$ & $3.64 b$ & $4.43 \mathrm{a}$ & $3.64 \mathrm{~A}$ & $1.90 \mathrm{~d}$ & $3.04 \mathrm{a}$ & $2.97 \mathrm{a}$ & $2.63 \mathrm{~A}$ \\
\hline Average B.F. & $2.52 \mathrm{~B}$ & $3.27 \mathrm{AB}$ & $3.93 \mathrm{~A}$ & & $1.69 \mathrm{~B}$ & $2.67 \mathrm{~A}$ & $2.64 \mathrm{~A}$ & \\
\hline
\end{tabular}

Means having the same letter(s) within the same column are not significantly different according to Duncans multiple range tests at $5 \%$ level of probability.

\section{Fruit set percentage $(\%)$}

Data in Table (4) reveled that all tested biofertilizers treatments increased fruit set percentage in compared to control treatment. Fruit set percentage was significantly affected with different biofertilization treatments in the both seasons. Nitrobein biofertilizer recorded the highest fruit set percentages (34.23 and $35.07 \%$ ), followed by rhizobacterin biofertilizer (33.57 and $34.36 \%)$ in both seasons, respectively. On the other contrary, control treatment gave the lowest values (29.01 and $30.39 \%$ ) in this respect, in both seasons. Humic acid at $150 \mathrm{~g} /$ tree treatment showed to be the most effective treatments in fruit set percentage (36.01 and $37.07 \%$ ) in both seasons, respectively. The interaction effect between biofertilization and humic acid treatments on fruit set percentage, results showed that nitrobein biofertilizer + humic acid at $150 \mathrm{~g} /$ tree induced more simulative effect in fruit set percentage (38.64 and $39.41 \%$ ) in the two seasons, respectively compared to other interactions. These results are in line with those obtained by Khattab et al. (2012) who reported that number of flowers per tree and fruit set were increased significantly with increasing rate of humic acid on pomegranate.

\section{Total yield (kg/ tree)}

Data presented in Table (4) indicated that biofertilization treatments were statistically increased Valencia orange cv., tree yield $(\mathrm{kg})$ with some variations in their effect when compared to the control treatment in the two seasons. Rhizobacterin treatment gave the highest yield (47.33 and $52.71 \mathrm{~kg} / \mathrm{tree})$, followed by nitrobein treatment $(46.23$ and $50.82 \mathrm{~kg} / \mathrm{tree}$ ) in both seasons, respectively. While, control (untreated of biofertilizer) treatment gave the lowest yield (33.09 and $37.78 \mathrm{~kg} / \mathrm{tree}$ ) in both seasons. The highest yields were given by humic acid at $150 \mathrm{~g} /$ tree (48.15 and $54.65 \mathrm{~kg} / \mathrm{tree})$ in both seasons. In the meantime, control treatment had the least yield (36.53 and $41.17 \mathrm{~kg} / \mathrm{tree})$ in both seasons. The increasing in total yield might be due to humic acid which enhanced uptake of mineral nutrients and increased cation exchange in soil as well as plant hormone like activity (Serenella et al., 2002). Regarding the interaction effect of biofertilization and humic acid treatments, the combinations between rhizobacterin biofertilization and humic acid at $150 \mathrm{~g} /$ tree gave the highest yield (54.71 and $62.37 \mathrm{~kg} / \mathrm{tree})$, while untreated treatment gave the lowest values (28.43 and $33.42 \mathrm{~kg} / \mathrm{tree}$ ) in the two seasons, respectively. Similar results were also reported by El-Razek et al. (2012) in peach, Asgharzade and Babaeian (2012) in grape, Khattab et al. (2012) in pomegranate and Ngullie et al. (2014) in mango. 
Table 4. Effect of humic acid and biofertilization treatments on fruit set percentage and total yield (kg/ tree) of Valencia orange trees during 2017 and 2018 seasons

\begin{tabular}{|c|c|c|c|c|c|c|c|c|}
\hline \multirow{2}{*}{$\begin{array}{l}\text { Humic acid } \\
\text { treatments }\end{array}$} & \multicolumn{4}{|c|}{ Fruit set percentage (\%) } & \multicolumn{4}{|c|}{ Total yield/ tree $(\mathrm{kg})$} \\
\hline & Control & Nitrobein & Rhizobacterin & $\begin{array}{c}\text { Average } \\
\text { H.A. }\end{array}$ & Control & Nitrobein & Rhizobacterin & $\begin{array}{c}\text { Average } \\
\text { H.A. }\end{array}$ \\
\hline \multicolumn{9}{|c|}{ Season 2017} \\
\hline Control & $25.58 \mathrm{~g}$ & $29.74 \mathrm{ef}$ & $30.25 \mathrm{e}$ & 28.52 D & $28.43 \mathrm{j}$ & $39.45 \mathrm{f}$ & $41.70 \mathrm{e}$ & 36.53 D \\
\hline $50 \mathrm{~g} /$ tree & $27.03 \mathrm{f}$ & $32.72 \mathrm{~d}$ & $31.62 \mathrm{de}$ & $30.46 \mathrm{C}$ & $32.18 \mathrm{i}$ & $44.69 \mathrm{de}$ & $45.73 \mathrm{~d}$ & $40.87 \mathrm{C}$ \\
\hline $100 \mathrm{~g} /$ tree & $30.88 \mathrm{e}$ & $35.82 \mathrm{c}$ & $35.55 \mathrm{c}$ & 34.08 B & $34.45 \mathrm{~h}$ & $48.32 \mathrm{bc}$ & $47.18 \mathrm{c}$ & 43.32 B \\
\hline $150 \mathrm{~g} /$ tree & $32.55 \mathrm{~d}$ & $38.64 \mathrm{a}$ & $36.84 \mathrm{~b}$ & 36.01 A & $37.29 \mathrm{~g}$ & $52.46 \mathrm{~b}$ & $54.71 \mathrm{a}$ & 48.15 A \\
\hline Average B.F. & $29.01 \mathrm{C}$ & $34.23 \mathrm{~A}$ & 33.57 B & & 33.09 C & $46.23 \mathrm{~B}$ & $47.33 \mathrm{~A}$ & \\
\hline \multicolumn{9}{|c|}{ Seas on 2018} \\
\hline Control & $26.54 \mathrm{i}$ & $30.63 \mathrm{~g}$ & $30.07 \mathrm{fg}$ & 29.08 D & $33.42 \mathrm{~h}$ & 44.55 ef & $45.54 \mathrm{e}$ & $41.17 \mathrm{C}$ \\
\hline $50 \mathrm{~g} /$ tree & $29.72 \mathrm{~h}$ & $33.33 \mathrm{e}$ & $33.64 \mathrm{e}$ & $32.23 \mathrm{C}$ & $36.36 \mathrm{gh}$ & $48.11 \mathrm{de}$ & $49.13 \mathrm{cde}$ & $44.53 \mathrm{BC}$ \\
\hline $100 \mathrm{~g} /$ tree & $31.54 \mathrm{f}$ & $36.89 \mathrm{c}$ & $35.68 \mathrm{~d}$ & $34.70 \mathrm{~B}$ & $38.42 \mathrm{~g}$ & $51.96 \mathrm{~cd}$ & $53.79 \mathrm{c}$ & 48.06 B \\
\hline $150 \mathrm{~g} /$ tree & $33.75 \mathrm{e}$ & $39.41 \mathrm{a}$ & $38.05 \mathrm{~b}$ & 37.07 A & $42.92 \mathrm{f}$ & $58.66 \mathrm{~b}$ & $62.37 \mathrm{a}$ & $54.65 \mathrm{~A}$ \\
\hline Average B.F. & $30.39 \mathrm{C}$ & 35.07 A & $34.36 \mathrm{~B}$ & & $37.78 \mathrm{C}$ & 50.82 B & $52.71 \mathrm{~A}$ & \\
\hline
\end{tabular}

Means having the same letter(s) within the same column are not significantly different according to Duncans multiple range tests at $5 \%$ level of probability.

\section{Fruit number per tree}

Results in Table (5) clear that nitrobein and rhizobacterin biofertilization gave the highest significantly in fruit umber per tree values (215.95 and 219.50) and (212.93 and 225.62) during the first and second seasons, respectively. Meanwhile, the lowest values noticed in control treatment (189.25 and 195.78) during the first and second seasons, respectively. The fruit number per tree was significantly affected with different humic acid treatments in both seasons respectively. Humic acid at $150 \mathrm{~g} /$ tree treatment gave the highest values in this respect since it was (214.96 and 222.26), followed by humic acid at $100 \mathrm{~g} /$ tree treatment (206.44 and 213.07) during first and second seasons, respectively. On the other side, untreated trees gave the lowest values of fruit umber per tree (201.93 and 209.23) during the first and second seasons, respectively. The interaction of rhizobacterin + humic acid at $150 \mathrm{~g} /$ tree treatment resulted in the highest fruit umber per tree (232.20 and 241.17), followed by nitrobein + humic acid at $150 \mathrm{~g} /$ tree treatment (228.61 and 229.93) in the first and second seasons, respectively. On the other hand, the least values of fruit number per tree were obtained by untreated trees since it was (200.38 and 202.29) in the first and second seasons, respectively. Other interactions were in between effects. Similarly, results were found by Samra et al. (2017) when working on Washington navel oranges and found that the fruit number per tree was significantly increased by increasing humic acid level up to $60 \mathrm{~g} /$ tree.

\section{Fruit physical characters}

\section{1- Fruit weight (g)}

Data presented in Table (5) indicated that fruit weight was significantly affected by different biofertilizer treatments in the two studied seasons. Rhizobacterin and nitrobein biofertilizers resulted in significantly the highest fruit weight (221.78 and $232.83 \mathrm{~g}$ ) and (213.51 and $231.05 \mathrm{~g}$ ) in the first, and second seasons, respectively as compared to control treatment. The humic acid treatments significantly increased fruit weight compared to control treatment in both seasons. Humic acid at $150 \mathrm{~g}$ / tree treatment significantly increased fruit weight (222.56 and $244.36 \mathrm{~g}$ ), followed by humic acid at $100 \mathrm{~g} /$ tree treatment (208.71 and $224.40 \mathrm{~g}$ ) in compared to other treatments during both seasons, respectively. The highest fruit weight was noticed with interaction of rhizobacterin or nitrobein biofertilizers with humic acid at $150 \mathrm{~g} /$ tree treatments (235.62 and $258.61 \mathrm{~g})$ and (229.47 and $255.12 \mathrm{~g}$ ) in the two seasons, respectively. In the meantime, the least values were given by untreated treatment (141.88 and $165.21 \mathrm{~g}$ ) in the two seasons, respectively. In accordance to these results, those previously reported by Fathy et al. (2010) on apricot trees, they found that the highest average fruit weight was recorded from trees that sprayed with humic acid. Chen et al. (2004) explained the effect of humic substances as the increase in fruit weight as a consequence of humic acid substance application after fruit set is probably ascribed to the uptake of mineral nutrients by the grapevines, but the possible hormone like activity of the humic acid substance (i.e., auxin-, gibberellin- and cytokinin-like activity). 
Table 5. Effect of humic acid and biofertilization treatments on average of fruit number/ tree and fruit weight $(\mathrm{g})$ of Valencia orange trees during 2017 and 2018 seasons

\begin{tabular}{|c|c|c|c|c|c|c|c|c|}
\hline \multirow{2}{*}{$\begin{array}{l}\text { Humic acid } \\
\text { treatments }\end{array}$} & \multicolumn{4}{|c|}{ Fruit number/ tree } & \multicolumn{4}{|c|}{ Fruit weight (g) } \\
\hline & Control & Nitrobein & Rhizobacterin & $\begin{array}{c}\text { Average } \\
\text { H.A. }\end{array}$ & Control & Nitrobein & Rhizobacterin & $\begin{array}{c}\text { Average } \\
\text { H.A. }\end{array}$ \\
\hline \multicolumn{9}{|c|}{ Season 2017} \\
\hline Control & $200.38 \mathrm{~d}$ & $202.63 \mathrm{~d}$ & $202.79 \mathrm{~d}$ & 201.93 B & $141.88 \mathrm{e}$ & $194.69 \mathrm{~cd}$ & $205.63 \mathrm{bcd}$ & $180.73 \mathrm{C}$ \\
\hline $50 \mathrm{~g} /$ tree & $185.34 \mathrm{e}$ & $211.77 \mathrm{c}$ & $205.39 \mathrm{~cd}$ & 200.83 B & $173.63 \mathrm{de}$ & $211.03 \mathrm{bc}$ & $222.65 \mathrm{ab}$ & 202.44 B \\
\hline $100 \mathrm{~g} /$ tree & $187.20 \mathrm{e}$ & 220.78 b & $211.35 \mathrm{c}$ & $206.44 \mathrm{AB}$ & $184.03 \mathrm{cde}$ & $218.86 \mathrm{~b}$ & $223.23 \mathrm{ab}$ & 208.71 B \\
\hline $150 \mathrm{~g} /$ tree & $184.08 \mathrm{e}$ & $228.61 \mathrm{a}$ & $232.20 \mathrm{a}$ & $214.96 \mathrm{~A}$ & $202.58 \mathrm{bcd}$ & $229.47 \mathrm{a}$ & $235.62 \mathrm{a}$ & $222.56 \mathrm{~A}$ \\
\hline Average B.F. & 189.25 B & $215.95 \mathrm{~A}$ & $212.93 \mathrm{~A}$ & & $175.53 \mathrm{C}$ & 213.51 A & $221.78 \mathrm{~A}$ & \\
\hline \multicolumn{9}{|c|}{ Seas on 2018} \\
\hline Control & $202.29 \mathrm{de}$ & $213.01 \mathrm{~d}$ & $212.39 \mathrm{~d}$ & $209.23 \mathrm{~B}$ & $165.21 \mathrm{f}$ & $209.15 d$ & $214.42 \mathrm{~cd}$ & 196.26 C \\
\hline $50 \mathrm{~g} /$ tree & $199.20 \mathrm{e}$ & 211.22 & $219.51 \mathrm{c}$ & 209.98 B & $182.53 \mathrm{e}$ & $227.77 \mathrm{bc}$ & $223.82 b c$ & 211.37 BC \\
\hline $100 \mathrm{~g} /$ tree & $185.97 \mathrm{f}$ & $223.83 \mathrm{~b}$ & $229.40 \mathrm{ab}$ & 213.07 AB & $206.59 \mathrm{de}$ & $232.14 \mathrm{~b}$ & 234.48 b & $224.40 \mathrm{~B}$ \\
\hline $150 \mathrm{~g} /$ tree & $195.66 \mathrm{e}$ & $229.93 \mathrm{ab}$ & 241.17 a & $222.26 \mathrm{~A}$ & $219.36 \mathrm{c}$ & $255.12 \mathrm{a}$ & 258.61 a & 244.36 A \\
\hline Average B.F. & $195.78 \mathrm{~B}$ & $219.50 \mathrm{~A}$ & 225.62 A & & 193.42 B & 231.05 A & 232.83 A & \\
\hline
\end{tabular}

Means having the same letter(s) within the same column are not significantly different according to Duncans multiple range tests at $5 \%$ level of probability.

\section{2- Fruit juice weight (g) and volume (ml)}

Concerning, specific effect of biofertilizer application on fruit juice weight and volume of Valencia cv., results in Table (6) indicted that fruit juice weight and volume were significantly affected with different biofertilizer treatments in both seasons. Nitrobein biofertilizer recorded the highest values in this respect since it was $(84.28$ and 83.15 g) and $(80.97$ and $92.31 \mathrm{ml})$ in the first and second season, respectively. On the other contrary, the lowest significant fruit juice weight and volume were observed with control treatment $(75.35$ and $79.01 \mathrm{~g})(55.87$ and $78.62 \mathrm{ml})$ in this respect during the first and second seasons, respectively. Fruit juice weight and volume were significantly affected by different humic acid treatments in both seasons. Humic acid at $150 \mathrm{~g} /$ tree treatment gave the highest fruit juice weight and volume (82.59 and $84.54 \mathrm{~g}$ ) and $(80.77$ and $94.77 \mathrm{ml})$ in the first and second seasons, respectively. While, untreated trees recorded the lowest fruit juice weight and volume (76.81 and $76.98 \mathrm{~g}$ ) and (58.49 and $69.87 \mathrm{ml}$ ) during both seasons of study respectively. As for interaction effect were significantly affected by different fertilizers and humic acid treatments. Nitrobein biofertilizer + humic acid at $150 \mathrm{~g} /$ tree treatment recorded the highest fruit juice weight and volume $(86.81$ and $85.58 \mathrm{~g})$ and $(96.50$ and $110.01 \mathrm{ml})$ in the first and second season, respectively. On the other hand, untreated trees gave the lowest values in this respect since it was (71.63 and $73.59 \mathrm{~g})$ and (47.22 and $63.41 \mathrm{ml}$ ) in the two seasons, respectively. Other interactions were intermediate. These results are in harmony with those obtained by of Fathy $\boldsymbol{e t} \boldsymbol{a l}$, (2010) on 'Canino' apricot and Ismail, et al. (2010) on Superior cv. grapevines.

\section{Fruit chemical parameters}

\section{1- Juice total soluble solids (TSS \%)}

Data in Table (7) indicated that fruit juice total soluble solids (TSS) was significantly affected by different biofertilization treatments in the two seasons. Both of rhizobacterin and nitrobein recorded the highest values in this respect (13.58 and $14.04 \%)$ and (13.29 and $13.73 \%)$ in 2017 and 2018 seasons, respectively. On the other hand, control treatment gave the lowest TSS percentage (10.82 and $11.88 \%$ ) in the first and second seasons, respectively. TSS \% was significantly affected by adding humic acid treatments in both seasons. Treated trees with humic acid at $150 \mathrm{~g} /$ tree resulted in significantly the highest percentage of TSS (13.50 and $14.31 \%$ ) in the first and second seasons, respectively. On the other side, the lowest percentage of TSS was obtained from untreated trees since it was (11.88 and $12.45 \%)$ in both seasons, respectively. With reference to the interaction effect between biofertilization and humic acid treatments on TSS, data in the same table showed that rhizobacterin or nitrobein biofertilization + humic acid at $150 \mathrm{~g} /$ tree induced more simulative effect in TSS percentage (14.57 and $15.19 \%$ ) and (14.33 and $14.92 \%$ ) in the both seasons, respectively compared to other interactions. The obtained results are in harmony with those previously reported by Ferrara and Brunetti (2010) and Abbas et al., (2013).

\section{2- Juice total acidity (\%)}

It is clear from Table (7) that juice acidity (\%) was decreased significantly affected with different biofertilizer treatments in both seasons. Control treatment gave the highest values in this respect 
since it was (1.60 and $1.41 \%)$ during both seasons, respectively. In contrary, rhizobacterin biofertilizer gave the lowest values of juice acidity (1.34 and $1.31 \%$ ) during the first and second seasons respectively. Nitrobein biofertilizer treatment was in between. Humic acid at $150 \mathrm{~g} /$ tree treatment significantly decreased juice acidity (1.39 and 1.24 $\%$ ) in both seasons, respectively. While, control treatment was the highest values (1.55 and $1.48 \%$ ) on juice acidity percentage during both seasons, respectively. The interaction effect between different biofertilizer with humic acid treatments showed a significant reduction in juice acidity percentage. The interaction between rhizobacterin with humic acid at $150 \mathrm{~g} /$ tree gave the least values $(1.28$ and $1.22 \%)$ compared to other interactions in both seasons, respectively. On the contrary, the untreated interaction treatment produced the highest juice acidity percentage and gave the highest values (1.69 and $1.56 \%$ ) in both seasons, respectively. The other interactions came in between effects. These data are in line with those obtained by Abbas et al. (2013).

Table 6. Effect of humic acid and biofertilization treatments on average juice weight and volume of Valencia orange fruits during 2017 and 2018 seasons

\begin{tabular}{|c|c|c|c|c|c|c|c|c|}
\hline \multirow{2}{*}{$\begin{array}{c}\text { Humic acid } \\
\text { treatments }\end{array}$} & \multicolumn{4}{|c|}{ Fruit juice weight (g) } & \multicolumn{4}{|c|}{ juice volume (ml) } \\
\hline & Control & Nitrobein & Rhizobacterin & $\begin{array}{c}\text { Average } \\
\text { H.A. }\end{array}$ & Control & Nitrobein & Rhizobacterin & $\begin{array}{c}\text { Average } \\
\text { H.A. }\end{array}$ \\
\hline \multicolumn{9}{|c|}{ Season 2017} \\
\hline Control & $71.63 \mathrm{e}$ & $80.37 \mathrm{bc}$ & $78.42 \mathrm{~cd}$ & $76.81 \mathrm{C}$ & $47.22 \mathrm{~h}$ & $68.43 \mathrm{~d}$ & $59.81 \mathrm{f}$ & 58.49 D \\
\hline $50 \mathrm{~g} /$ tree & $74.72 \mathrm{de}$ & $84.29 \mathrm{ab}$ & $79.69 \mathrm{bcd}$ & 79.57 B & $50.94 \mathrm{~g}$ & $73.83 \mathrm{c}$ & $72.50 \mathrm{~cd}$ & $65.76 \mathrm{C}$ \\
\hline $100 \mathrm{~g} /$ tree & $75.68 \mathrm{~d}$ & $85.66 \mathrm{a}$ & $80.23 \mathrm{bc}$ & 80.52 AB & $58.74 \mathrm{fg}$ & $85.13 \mathrm{~b}$ & $85.08 \mathrm{~b}$ & 76.32 B \\
\hline $150 \mathrm{~g} /$ tree & $79.37 \mathrm{~b} \mathrm{~cd}$ & $86.81 \mathrm{a}$ & $81.58 \mathrm{~b}$ & 82.59 A & $66.59 \mathrm{e}$ & $96.50 \mathrm{a}$ & $79.22 \mathrm{bc}$ & 80.77 A \\
\hline Average B.F. & 75.35 C & $84.28 \mathrm{~A}$ & $79.98 \mathrm{~B}$ & & 55.87 C & 80.97 A & 74.15 B & \\
\hline \multicolumn{9}{|c|}{ Season 2018} \\
\hline Control & $73.59 \mathrm{e}$ & $80.11 \mathrm{c}$ & $77.24 \mathrm{~d}$ & $76.98 \mathrm{C}$ & $63.41 \mathrm{~g}$ & $78.01 \mathrm{de}$ & $68.18 \mathrm{f}$ & 69.87 C \\
\hline $50 \mathrm{~g} /$ tree & $77.33 \mathrm{~d}$ & $82.27 \mathrm{bc}$ & $79.23 \mathrm{~cd}$ & $79.61 \mathrm{~B}$ & $76.86 \mathrm{e}$ & $84.17 \mathrm{c}$ & 82.65 cde & 81.23 B \\
\hline $100 \mathrm{~g} /$ tree & $81.45 \mathrm{bc}$ & $84.63 \mathrm{ab}$ & $83.79 \mathrm{abc}$ & 83.29 A & $90.20 \mathrm{bc}$ & $97.05 \mathrm{ab}$ & $96.99 \mathrm{abc}$ & $94.75 \mathrm{~A}$ \\
\hline $150 \mathrm{~g} /$ tree & $83.67 \mathrm{abc}$ & $85.58 \mathrm{a}$ & $84.37 \mathrm{ab}$ & 84.54 A & $83.99 \mathrm{~cd}$ & $110.01 \mathrm{a}$ & $90.31 \mathrm{bc}$ & 94.77 A \\
\hline Average B.F. & 79.01 B & 83.15 A & 81.16 AB & & $78.62 \mathrm{C}$ & $92.31 \mathrm{~A}$ & 84.53 B & \\
\hline
\end{tabular}

Means having the same letter(s) within the same column are not significantly different according to Duncans multiple range tests at $5 \%$ level of probability.

Table 7. Effect of humic acid and biofertilization treatments on TSS and total acidity percentages of Valencia orange fruit juice during 2017 and 2018 seasons

\begin{tabular}{|c|c|c|c|c|c|c|c|c|}
\hline \multirow{2}{*}{$\begin{array}{l}\text { Humic acid } \\
\text { treatments }\end{array}$} & \multicolumn{4}{|c|}{$\operatorname{TSS}(\%)$} & \multicolumn{4}{|c|}{ Total acidity (\%) } \\
\hline & Control & Nitrobein & Rhizobacterin & $\begin{array}{c}\text { Average } \\
\text { H.A. }\end{array}$ & Control & Nitrobein & Rhizobacterin & $\begin{array}{c}\text { Average } \\
\text { H.A. }\end{array}$ \\
\hline \multicolumn{9}{|c|}{ Season 2017} \\
\hline Control & $10.24 \mathrm{~g}$ & $12.53 \mathrm{~d}$ & $12.87 \mathrm{~d}$ & $11.88 \mathrm{C}$ & $1.69 \mathrm{a}$ & $1.56 \mathrm{ab}$ & $1.41 \mathrm{bc}$ & $1.55 \mathrm{~A}$ \\
\hline $50 \mathrm{~g} /$ tree & $10.52 \mathrm{fg}$ & $12.90 \mathrm{~cd}$ & $13.12 \mathrm{c}$ & 12.18 BC & $1.61 \mathrm{a}$ & $1.49 a b c$ & $1.36 \mathrm{bcd}$ & $1.49 \mathrm{AB}$ \\
\hline $100 \mathrm{~g} /$ tree & $10.90 \mathrm{f}$ & $13.40 \mathrm{bc}$ & $13.74 \mathrm{~b}$ & $12.68 \mathrm{~B}$ & $1.56 \mathrm{ab}$ & $1.42 \mathrm{bc}$ & $1.32 \mathrm{~cd}$ & $1.43 \mathrm{~B}$ \\
\hline $150 \mathrm{~g} /$ tree & $11.61 \mathrm{e}$ & $14.33 \mathrm{a}$ & $14.57 \mathrm{a}$ & $13.50 \mathrm{~A}$ & $1.55 \mathrm{ab}$ & $1.35 \mathrm{bcd}$ & $1.28 \mathrm{~d}$ & $1.39 \mathrm{~B}$ \\
\hline Average B.F. & $10.82 \mathrm{~B}$ & $13.29 \mathrm{~A}$ & $13.58 \mathrm{~A}$ & & $1.60 \mathrm{~A}$ & $1.46 \mathrm{AB}$ & $1.34 \mathrm{~B}$ & \\
\hline \multicolumn{9}{|c|}{ Season 2018} \\
\hline Control & $11.23 \mathrm{e}$ & $12.86 \mathrm{~cd}$ & $13.25 \mathrm{c}$ & $12.45 \mathrm{C}$ & $1.56 \mathrm{a}$ & $1.47 \mathrm{ab}$ & $1.42 \mathrm{abc}$ & $1.48 \mathrm{~A}$ \\
\hline $50 \mathrm{~g} /$ tree & $11.44 \mathrm{de}$ & $13.29 \mathrm{c}$ & $13.51 \mathrm{bc}$ & $12.75 \mathrm{BC}$ & $1.43 \mathrm{abc}$ & $1.39 \mathrm{bc}$ & $1.37 \mathrm{bc}$ & $1.40 \mathrm{~B}$ \\
\hline $100 \mathrm{~g} /$ tree & $12.04 \mathrm{~d}$ & $13.86 \mathrm{abc}$ & $14.20 \mathrm{ab}$ & 13.37 B & $1.36 \mathrm{bc}$ & $1.31 \mathrm{bcd}$ & $1.24 \mathrm{~cd}$ & $1.30 \mathrm{C}$ \\
\hline $150 \mathrm{~g} /$ tree & $12.82 \mathrm{~cd}$ & $14.92 \mathrm{a}$ & $15.19 \mathrm{a}$ & $14.31 \mathrm{~A}$ & $1.28 \mathrm{bcd}$ & $1.23 \mathrm{~cd}$ & $1.22 \mathrm{~d}$ & $1.24 \mathrm{D}$ \\
\hline Average B.F. & $11.88 \mathrm{~B}$ & $13.73 \mathrm{~A}$ & $14.04 \mathrm{~A}$ & & $1.41 \mathrm{~A}$ & $1.35 \mathrm{AB}$ & $1.31 \mathrm{~B}$ & \\
\hline
\end{tabular}

Means having the same letter(s) within the same column are not significantly different according to Duncans multiple range tests at $5 \%$ level of probability. 


\section{3- Juice $\mathrm{TSS} /$ acid ratio}

The obtained results in Table (8) reveled that all tested biofertilizers treatments increased juice TSS/ acid ratio in compared to control treatment. Juice TSS/ acid ratio was significantly recorded the highest juice TSS/ acid ratio (10.14) in the first season, while, rhizobacterin and nitrobein treatments recorded the highest values (10.77 and 10.25) in the second season, respectively. On the other contrary, control treatment gave the lowest values of TSS/ acid ratio (6.77 and 8.52) in this respect in both seasons. Humic acid at $150 \mathrm{~g} /$ tree treatment showed to be the most effective treatments in juice TSS/ acid ratio (9.83 and 11.53) in both seasons, respectively. On the contrary, control treatment caused a significant reduction in this respect. The interaction of rhizobacterin biofertilization + humic acid at $150 \mathrm{~g} /$ tree induced more simulative effect in juice TSS/ acid ratio (11.38 and 12.45) in the both seasons, respectively compared to other interactions. These findings are in line with Medhi et al. (2007) reported highest TSS and minimum acidity percentage by application biofertilizers in Khasi mandarin. The microbial fertilizers enhance the nutrient availability by increasing the capability of plants to better solute uptake from rhizosphere (Patel et al., 2009). Sah et al. (2010) reported that VAM converts the unavailable nutrient from rhizosphere soil to available forms resulting increased uptake of nutrient. Besides increased nutrient absorbing area of root, so increase in the chemical quality of fruits may be due to beneficial and stimulatory effect of nitrogen and other nutrient.

\section{4- Ascorbic acid (vitamin $\mathrm{C}$ content $\mathrm{mg} / 100 \mathrm{ml}$ juice)}

Data presented in Table (8) showed that ascorbic acid as vitamin C content (mg/ $100 \mathrm{ml}$ juice) was significantly increased under different biofertilization compared to control treatment in both seasons, rhizobacterin and nitrobein biofertilization treatments were significantly increased vitamin C content (49.03 and $50.86 \mathrm{mg}$ / $100 \mathrm{ml}$ juice) and (48.19 and $49.38 \mathrm{mg} / 100 \mathrm{ml}$ juice) when compared to control treatment which recorded lowest values (42.20 and $42.55 \mathrm{mg} / 100 \mathrm{ml}$ juice) in both seasons, respectively. Humic acid at $150 \mathrm{~g} /$ tree gave the highest significantly in vitamin $\mathrm{C}$ content values (48.75 and $50.17 \mathrm{mg} / 100 \mathrm{ml}$ juice), followed by humic acid at $100 \mathrm{~g} /$ tree treatment (46.92 and $47.58 \mathrm{mg} / 100 \mathrm{ml}$ juice) in the first and second season, respectively, while control (untreated of humic acid) treatment was the lowest values (44.19 and $45.86 \mathrm{mg} / 100 \mathrm{ml}$ juice) during in the two seasons, respectively. It might be due to humic acid increase the permeability of bio membranes for electrolytes accounted for increased uptake of phosphorus and potassium which increase the ascorbic acid percentage of the fruit (Sindha $\boldsymbol{e t}$ al., 2018). The interaction of treating trees with rhizobacterin or nitrobein + humic acid at $150 \mathrm{~g} /$ tree gave the highest vitamin $\mathrm{C}$ content (52.17 and 53.74 $\mathrm{mg} / 100 \mathrm{ml}$ juice) and (51.69 and $52.72 \mathrm{mg} / 100 \mathrm{ml}$ juice) compared to other interactions during both seasons. While, untreated treatment gave the lowest vitamin $C$ content values (41.09 and $42.88 \mathrm{mg} / 100$ $\mathrm{ml}$ juice) in the first and second season, respectively. These data are in line with those obtained by Abbas et al., (2013) on Kinnow mandarin and Sindha et al. (2018) on custard apple cv. local.

Table 8. Effect of humic acid and biofertilization treatments on TSS/ acid ratio and vitamin C content of Valencia orange fruit juice during 2017 and 2018 seasons

\begin{tabular}{|c|c|c|c|c|c|c|c|c|}
\hline \multirow{2}{*}{$\begin{array}{l}\text { Humic acid } \\
\text { treatments }\end{array}$} & \multicolumn{4}{|c|}{ TSS/ acid ratio } & \multicolumn{4}{|c|}{ Vitamin $C$ content (mg/ $100 \mathrm{ml}$ juice) } \\
\hline & Control & Nitrobein & Rhizobacterin & $\begin{array}{c}\text { Average } \\
\text { H.A. }\end{array}$ & Control & Nitrobein & Rhizobacterin & $\begin{array}{c}\text { Average } \\
\text { H.A. }\end{array}$ \\
\hline \multicolumn{9}{|c|}{ Seas on 2017} \\
\hline Control & $6.06 \mathrm{~g}$ & $8.03 \mathrm{de}$ & $9.13 \mathrm{~cd}$ & $7.74 \mathrm{C}$ & $41.09 \mathrm{f}$ & $45.15 \mathrm{~d}$ & $46.33 \mathrm{c}$ & 44.19 C \\
\hline $50 \mathrm{~g} /$ tree & $6.53 \mathrm{fg}$ & $8.66 \mathrm{~d}$ & $9.65 \mathrm{bc}$ & $8.28 \mathrm{BC}$ & $42.46 \mathrm{e}$ & $47.18 \mathrm{bc}$ & $48.47 \mathrm{abc}$ & 46.04 B \\
\hline $100 \mathrm{~g} /$ tree & $6.99 \mathrm{f}$ & $9.44 \mathrm{bcd}$ & $10.41 \mathrm{~b}$ & 8.94 B & $42.88 \mathrm{e}$ & $48.73 \mathrm{abc}$ & $49.15 \mathrm{ab}$ & 46.92 B \\
\hline $150 \mathrm{~g} /$ tree & $7.49 \mathrm{e}$ & $10.61 \mathrm{~b}$ & $11.38 \mathrm{a}$ & $9.83 \mathrm{~A}$ & $42.39 \mathrm{e}$ & $51.69 \mathrm{a}$ & $52.17 \mathrm{a}$ & $48.75 \mathrm{~A}$ \\
\hline Average B.F. & $6.77 \mathrm{C}$ & $9.19 \mathrm{~B}$ & $10.14 \mathrm{~A}$ & & $42.20 \mathrm{~B}$ & $48.19 \mathrm{~A}$ & $49.03 \mathrm{~A}$ & \\
\hline \multicolumn{9}{|c|}{ Seas on 2018} \\
\hline Control & $7.20 \mathrm{f}$ & $8.75 \mathrm{de}$ & $9.33 \mathrm{~d}$ & $8.43 \mathrm{C}$ & $42.88 \mathrm{f}$ & $46.50 \mathrm{~cd}$ & $48.18 \mathrm{c}$ & $45.86 \mathrm{C}$ \\
\hline $50 \mathrm{~g} /$ tree & $8.00 \mathrm{e}$ & $9.56 \mathrm{~cd}$ & $9.86 \mathrm{bcd}$ & $9.14 \mathrm{~B}$ & $41.34 \mathrm{e}$ & $48.60 \mathrm{c}$ & $50.41 \mathrm{~b}$ & $6.78 \mathrm{BC}$ \\
\hline $100 \mathrm{~g} /$ tree & $8.85 \mathrm{de}$ & $10.58 \mathrm{~b}$ & $11.45 \mathrm{ab}$ & $10.29 \mathrm{AB}$ & $41.92 \mathrm{e}$ & $49.70 \mathrm{bc}$ & $51.12 \mathrm{ab}$ & $47.58 \mathrm{~B}$ \\
\hline $150 \mathrm{~g} /$ tree & $10.02 \mathrm{bc}$ & $12.13 \mathrm{a}$ & $12.45 \mathrm{a}$ & $11.53 \mathrm{~A}$ & $44.06 \mathrm{~d}$ & $52.72 \mathrm{a}$ & $53.74 \mathrm{a}$ & 50.17 A \\
\hline Average B.F. & $8.52 \mathrm{~B}$ & $10.25 \mathrm{~A}$ & $10.77 \mathrm{~A}$ & & 42.55 B & 49.38 A & 50.86 A & \\
\hline
\end{tabular}

Means having the same letter(s) within the same column are not significantly different according to Duncans multiple range tests at $5 \%$ level of probability. 


\section{5- Total sugars (\%)}

As for, specific effect biofertilization treatments, data in the Table (9) illustrated that total sugars percentage was increased significantly affected with different biofertilizer treatments in both seasons. Rhizobacterin biofertilizer treatment gave the highest values of total sugars percentage (9.69 and $11.04 \%$ ), followed by Nitrobein biofertilizer treatment $(9.31$ and $10.61 \%)$ in the two seasons, respectively. In contrary, control treatment gave the lowest values of total sugars percentage $(8.67$ and $9.87 \%$ ) during the first and second seasons respectively. Humic acid at $150 \mathrm{~g} /$ tree treatment significantly increased total sugars percentage $(10.20$ and $11.60 \%)$ in both seasons, respectively. While, control treatment was the lowest values of total sugars percentage $(8.54$ and $9.71 \%)$ during both seasons, respectively. The increase in total sugar in response to humic acid might be due to formation of maximum amount of carbohydrate within the leaf and fruit tissues, which than converted to the specific sugar like glucose and sucrose (Abbas et al., 2013). The interaction between rhizobacterin with humic acid at $150 \mathrm{~g} /$ tree gave the highest values (10.78 and $12.29 \%)$, followed by nitrobein with humic acid at $150 \mathrm{~g} /$ tree (10.23 and $11.66 \%$ ) compared to other interactions in both seasons, respectively. On the contrary, the untreated interaction treatment gave the lowest values (8.04 and $9.08 \%)$ in both seasons, respectively. The other interactions came in between effects. Similar finding was also reported by Zachariakis et al. (2001) in grape, which discussed that the increase in sugars in response to humic acid might be due to formation of maximum amount of different forms of carbohydrates within the leaf and fruit tissues of grapevine, which are then converted to the specific sugars like glucose and sucrose.

\section{6- Reducing sugars (\%)}

Data in Table (9) indicted that reducing sugars (\%) was decreased significantly affected with different biofertilizer treatments in both seasons. Control treatment gave the highest values of reducing sugars (6.42 and $6.52 \%)$ during both seasons, respectively. In contrary, Rhizobacterin biofertilizer gave the lowest values of reducing sugars percentage (4.52 and $5.16 \%$ ) during the first and second seasons respectively. Nitrobein biofertilizer treatment was in between. Humic acid at $150 \mathrm{~g} /$ tree treatment significantly decreased reducing sugars percentage (4.68 and $5.03 \%$ ) in both seasons, respectively. While, control treatment was the highest values (5.95 and $6.31 \%$ ) on reducing sugars percentage during both seasons, respectively. The interaction of different biofertilizer with humic acid treatments showed a significant reduction in reducing sugars percentage. The interaction between rhizobacterin with humic acid at $150 \mathrm{~g} /$ tree gave the least values (3.92 and $4.63 \%$ ) compared to other interactions in both seasons, respectively. On the contrary, the untreated treatment produced the highest reducing sugars percentage and gave the highest values (6.95 and $7.02 \%)$ in both seasons, respectively. The other interactions came in between effects.

Table 9. Effect of humic acid and biofertilization treatments on total and reducing sugars percentages of Valencia orange fruit juice during 2017 and 2018 seasons

\begin{tabular}{|c|c|c|c|c|c|c|c|c|}
\hline \multirow{2}{*}{$\begin{array}{l}\text { Humic acid } \\
\text { treatments }\end{array}$} & \multicolumn{4}{|c|}{ Total sugars (\%) } & \multicolumn{4}{|c|}{ Reducing sugars (\%) } \\
\hline & Control & Nitrobein & Rhizobacterin & $\begin{array}{c}\text { Average } \\
\text { H.A. }\end{array}$ & Control & Nitrobein & Rhizobacterin & $\begin{array}{c}\text { Average } \\
\text { H.A. }\end{array}$ \\
\hline \multicolumn{9}{|c|}{ Season 2017} \\
\hline Control & $8.04 \mathrm{f}$ & $8.56 \mathrm{de}$ & $9.03 \mathrm{bcd}$ & $8.54 \mathrm{~B}$ & $6.95 \mathrm{a}$ & $5.77 \mathrm{~b}$ & $5.14 \mathrm{bc}$ & $5.95 \mathrm{~A}$ \\
\hline $50 \mathrm{~g} /$ tree & $8.17 \mathrm{e}$ & $8.95 \mathrm{~cd}$ & $9.18 \mathrm{bc}$ & $8.77 \mathrm{~B}$ & $6.71 \mathrm{a}$ & $5.13 \mathrm{bc}$ & $4.82 \mathrm{c}$ & $5.55 \mathrm{~A}$ \\
\hline $100 \mathrm{~g} /$ tree & $8.88 \mathrm{~d}$ & $9.48 \mathrm{~b}$ & $9.76 \mathrm{ab}$ & $9.37 \mathrm{AB}$ & $6.34 \mathrm{ab}$ & $4.74 \mathrm{~cd}$ & $4.22 \mathrm{de}$ & $5.10 \mathrm{AB}$ \\
\hline $150 \mathrm{~g} /$ tree & $9.59 \mathrm{~b}$ & $10.23 \mathrm{a}$ & $10.78 \mathrm{a}$ & $10.20 \mathrm{~A}$ & $5.68 \mathrm{~b}$ & $4.45 \mathrm{~d}$ & $3.92 \mathrm{e}$ & $4.68 \mathrm{~B}$ \\
\hline Average B.F. & $8.67 \mathrm{~B}$ & $9.31 \mathrm{~A}$ & $9.69 \mathrm{~A}$ & & $6.42 \mathrm{~A}$ & $5.02 \mathrm{~B}$ & $4.52 \mathrm{C}$ & \\
\hline \multicolumn{9}{|c|}{ Season 2018} \\
\hline Control & $9.08 \mathrm{f}$ & $9.76 \mathrm{de}$ & $10.29 \mathrm{~cd}$ & $9.71 \mathrm{C}$ & $7.02 \mathrm{a}$ & $5.90 \mathrm{~b}$ & $6.00 \mathrm{~b}$ & $6.31 \mathrm{~A}$ \\
\hline $50 \mathrm{~g} /$ tree & $9.49 \mathrm{de}$ & $10.20 \mathrm{~cd}$ & $10.47 \mathrm{bcd}$ & $10.05 \mathrm{BC}$ & $6.84 \mathrm{a}$ & $5.75 \mathrm{bc}$ & $5.18 \mathrm{~cd}$ & $5.92 \mathrm{~A}$ \\
\hline $100 \mathrm{~g} /$ tree & $10.05 \mathrm{~d}$ & $10.81 \mathrm{bc}$ & $11.13 \mathrm{~b}$ & $10.66 \mathrm{~B}$ & $6.53 \mathrm{ab}$ & $5.49 \mathrm{c}$ & $4.83 \mathrm{~d}$ & $5.62 \mathrm{AB}$ \\
\hline $150 \mathrm{~g} /$ tree & $10.85 \mathrm{bc}$ & $11.66 \mathrm{ab}$ & $12.29 \mathrm{a}$ & $11.60 \mathrm{~A}$ & $5.68 \mathrm{bc}$ & $4.77 \mathrm{de}$ & $4.63 \mathrm{e}$ & $5.03 \mathrm{~B}$ \\
\hline Average B.F. & $9.87 \mathrm{~B}$ & $10.61 \mathrm{AB}$ & $11.04 \mathrm{~A}$ & & $6.52 \mathrm{~A}$ & $5.48 \mathrm{~B}$ & $5.16 \mathrm{~B}$ & \\
\hline
\end{tabular}

Means having the same letter(s) within the same column are not significantly different according to Duncans multiple range tests at $5 \%$ level of probability. 


\section{CONCLUSION}

As a conclusion, from the abovementioned results we can conclude that all application of different levels of humic acid alone or in combination with biofertilizers had a positive effect on increased flowering characteristics as well as fruit set percentage, total yield and improved fruit characters of Valencia orange trees. In addition, interaction treatment between rhizobacterin and humic acid at $150 \mathrm{~g} /$ tree was the most effective treatment in enhancing flowering parameters (leafy inflorescences and flowering percentage on leafy and woody inflorescences) as well as; total yield, fruit weight, juice total soluble solids (TSS), juice TSS/ acid ratio, ascorbic acid (vitamin C content) and total sugars and reducing woody inflorescences, juice acidity and reducing sugars. In addition, fruit set percentage, fruit juice weight and volume were the best from trees treated with nitrobein biofertilizer + humic acid at $150 \mathrm{~g} /$ tree.

\section{REFERENCES}

A.O.A.C. (1995). Association of Official Agricultural Chemists: Official Methods of Analysis. Washington, DC., USA, 12 Ed., pp. 494500.

Abbas, T; Ahmad, S.; Ashraf, M.; Adnan, M.; Yasin, M. and Balal, R. M. (2013). Effect of humic and application at different growth stages of Kinnow mandarin (citrus reticulate Blanco) on the basis of physio-biochemical and reproductive responses. Academia J. Biotech., 1(1): 014-020.

Abd El-Rhman, I. E. (2017). Effect of magnetic iron and potassium humate on growth, yield and fruit quality of pomegranate trees in Siwa oasis, Egypt. Intern. J. Environ., 6 (3): 103- 113.

Abd-Alhamid, N.; Hassan, H. S. A.; Laila F. Haggag and Hassan, A. M. (2015). Effect of mineral and biofertilization on vegetative growth, leaf mineral contents and flowering of Manzanillo olive trees. Intern. J. ChemTech Res., 8(11): 51-61.

Abobatta, W. F. (2014). Effect of humates compounds and magnetic iron on growth and fruiting of Valencia orange trees (Citrus sinensis L.)., Ph.D. Thesis, Agric. (Hort.), Fac. Agric., Minoufiya Univ., Egypt.

Abobatta, W. F. (2018). Development growth and productivity of orange orchards (Citrus Sinensis L) in Egypt (Delta Region). Advances Agric. Techno. Plant Sci., 1(1): 1-11.

Annual Reports of Statistical Institute and Agricultural Economic Research in Egypt (2018). Citrus annual Egyptian orange exports continue to expand. Ministry of Agriculture and Land Reclamation, Egypt.

Aseri, G. K.; Jain, N.; Panwar, J.; Raoan, A. V. and Meghwal, P. R. (2008). Bio-fertilizers improve plant growth, fruit yield, nutrition, metabolism and rhizosphere enzyme activities of Pomegranate (Punica granatum L.) in Indian Thar Desert. Scientia Horticulturae, 117: 130- 135

Asgharzade, A. and Babaeian, M. (2012). Investigating the effect of humic acid and acetic acid foliar application on yield and leaves nutrient content of grape (Vitis vinifera). African J. Microbiol. Res., 6(31): 6049-6054.

Chen, Y.; Nobili, M. De and Aviad, T. (2004). Stimulatory effect of humic substances on plant growth. In 'Soil organic matter in sustainable agriculture' (Eds F Magdoff, RR Weil) pp. 103-130. CRC Press: Boca Raton,FL.

Duncan, B. D. (1955). Multiple range and multiple Ftests. Biometrics, 11: 1-42.

Eissa, F.M. (2003). Use of some biostimulants in activation of soil microflora for yield and fruit quality improvement of 'Canino' apricot. J. Agric. Res. Tanta Univ., 29(1).

El-Badawy, H. E. M. (2017). Partial substitution of Valencia orange chemical fertilization by bioorganic fertilization conjoint with algae extract foliar spray. Middle East J. Appl. Sci., 7(4): 1016- 1030.

El-Khawaga, A. S. (2007). Selecting the optimum amount of organic, mineral and biofertilizers responsible for maximizing the productivity of Balady guava. Egypt. J. Appl. Sci., 22 (5B).

El-Khawaga, A. S. and Maklad, M. F. (2013). Effect of combination between bio and chemical fertilization on vegetative growth, yield and quality of Valencia orange fruits. Hortscience J. Suez Canal Univ., 1: 269-279.

El-Razek, E. A.; Abd-Allah, A.S.E. and Saleh, M. M. S. (2012). Yield and fruit quality of 'Florida Prince' peach trees as affected by foliar and soil applications of humic acid. J. Appl. Sci. Res. 8(12): 5724-5729.

Farag, S. G. (2006). Minimizing mineral fertilizers in grapevine farms $M$. Sc. Thesis institute of environmental studies and research, Ain Shams Univ., Egypt.

Fathy, M.A.; Gabr, M.A. and El Shall, S.A. (2010). Effect of humic acid treatments on 'Canino' apricot growth, yield and fruit quality. New York Sci. J., 3(12): 109-115.

Ferrara, G. and Brunetti, G. (2010). Effects of the times of application of a soil humic acid on berry 
quality of table grape (Vitis vinifera L.) cv. Italia. Spanish J. Agric. Res., 8(3): 817-822.

GOAEF, General Organization for Agriculture Equalization Fund (1999). Ministry of Agric. Biogen, phosphorien, nitrobien and potassien bulletins.

Hidayatullah, A. K.; Mouladad, M.; Mirwise, M.; Nisar, A. and Azmatullah, S. (2018). Effect of humic acid on fruit yield attributes, yield and leaf nutrient accumulation of Apple trees under calcareous soil. Indian J. Sci. Techno., 11 (15): 10. 17485/ijst/2018/v11i15/119931

Hikal, A.R.F. (2000). Physiological studies on nutrition of Washington Navel orange trees. Ph.D. Thesis, Fac. Agric., Mansoura Univ., Egypt.

Ismail, A.E.; Soliman, S.S.; Abd-El-Moniem, E.M.; Awad, M.S. and Rashad Azza, A. (2010). Effect of magnetic iron ore, metal compound fertilizer and bio-NK in controlling root -rot nematode of grapevine in a newly reclaimed area of Egypt. Pakistan. J. Nematol., 28(2): 307-328.

Jugnake, M.O.; Patil, M.B. and Shinde, S.E. (2017). Effect of biofertilizer and chemical fertilizer on growth and yield of sweet orange (Citrus sinensis L. Osbeck). Intern. J. Chemical Studies, 5(6): 10611064.

Khattab, M.M; Shaban, A. E.; El-Shrief, A. H. and El-Deen, A. S. (2012). Effect of humic acid and amino acids on pomegranate trees under deficit irrigation on growth, flowering and fruiting. J. Hort. Sci. \& Ornamental Plants, 4(3): 253-259.

Lane, H. and Eynon, S. I. (1960). Analysis of fruit and vegetable priducts. Reducing and total sugars determination. Published by British Crop Production, 4th Edition, 9-13.

Mahfouz, S.A. and Sharaf-Eldin, M.A. (2007). Effect of mineral vs. biofertilizer on growth, yield and essential oil content of fennel (Foeniculum vulgare Mill.). Intern. Agron. Physics, 21: 361-366.

Medhi, B.K.; Saikia, A. J.; Bora, S. C.; Hazarika, T. K. and Barbora, A. C. (2007). Integrated use of concentrated organic manures, biofertilizers and inorganic NPK on yield, quality and nutrient content of Khasi Mandarin (Citrus reticulata Blanco.). Indian J. agric. Res., 41(4): 235-241.

Montasser, A.S.; El-Shahat, N.; Ghoberial, G.F. and El-Wadoud, M.Z. (2003). Residual effect of nitrogen fertilization on leaves and fruits of
Thompson seedlees grapes. J. Environ. Sci., 6: 465484.

Ngullie C. R; Tank, R. V. and Bhanderi, D. R. (2014). Effect of salicylic acid and humic acid on flowering, fruiting, yield and quality of mango (Mangifera indica L.) cv. Kesar. Adv. Res. J. crop Improve, 5(2): 136-139.

Page, A. L.; Miller, R. H. and Keeney, D. R. (1982). Methods of soil analysis part 2: chemical and microbiological properties second edition. Agronomy 920 Am. Soc. Agron. Inc. Soil Sci. Soc. Am. Inc. Pub. Madison, Wisconsin, USA.

Patel, V.B.; Singh, S. K.; Asrey, R.; Nain, L.; Singh, A.K. and Laxman, S. (2009). Microbial and inorganic fertilizers application influenced vegetative growth, yield, leaf nutrient status and soil microbial biomass in sweet orange cv. MOSAMBI. Indian J. Hort., 66(2): 163-168.

Russell, D. F. (1986). MSTATC Director, Crop and Soil Sciences Department, Michigan State University, Computer Program Package Version 2.10 .

Sah, H.; Rai, P.N; and Manoj, K. (2010). Effect of biofertilizer on growth, yield and quality of low chill pear cv. GOLA. Haryana J. Hort. Sci.,39(3\&4): 179181.

Samra, N. R.; EL-Kady, M. I.; Hikal, A. R. and Ghanem, M. S. H. (2017). Effect of organic fertilization on fruit set, dropping, yield and fruit quality of Washington navel orange. J. Plant Production, Mansoura Univ., 8 (8): 853-858.

Serenella, N.; Pizzeghelloa, D.; Muscolob, A. and Vianello, A. (2002). Physiological effect of humic substances on higher plants. Soil Biology and Biochemistry, 34: 1527-1536.

Sindha, D. J.; Satodiya, B.N. and Sutariya, N.K. (2018). Effect of foliar application of different chemicals and humic acid on fruit yield and quality of custard apple (Annona squamosa L.) cv. local. Intern. J. Chemical Studies, 6(5): 75-77.

Youssef, M. M. A. and Eissa, M. F. M. (2014). Biofertilizers and their role in management of plant parasitic nematodes. E3 J. Biotech. and Pharma, 5(1):001-006.

Zachariakis, A.; Tzorakakis, E.; Kritsotakis, I.; Siminis, C. I. and Manios, V. (2001). Humic substance stimulate plant growth and nutrient accumulation in grapevine rootstocks. Acta. Hort., 549:131-136. 